\title{
Det hvide guld og det aegte guld - minedrift og råstoffer i Gronlands 20. århundrede
}

Anmeldt af geolog Ulla V. Hjuler, GeologiskNyt

Den 22. juni i år udgav GEUS en flot bog i "kalenderform" om minedriften af først kryolit (det "hvide" guld) og siden af det ægte guld i Grønland. Bogen fortæller for hvert år startende fra 1901 og 100 år frem den spændende historie om Grønlands minedrift og råstoffer.

Mineaktiviteten påbegyndtes i Grønland $\mathrm{i}$ starten af 1800-tallet. Kryolitbrydning havde fundet sted i Ivittuut siden $1854 \mathrm{og}$ forskellige andre aktiviteter som bly- og kobberminer var også igangsat, og desuden brød man også kul og zirkonium.

På daværende tidspunkt stammede den geologiske viden primært far en tysk minera$\log$, Giesecke, der førte dagbog over sine observationer og lokale oplysninger. Geologisk Museums medarbejdere var fra sidst $\mathrm{i}$ 1800-tallet de dominerende i udforskningen.

Herefter giver bogen et kort, men fyndig oprids af den stigende interesse for de geologiske aktiviteter i Grønland - bl.a. den omfangsrige eksport af kryolit til USA under 2. Verdenskrig.

\section{Udvalgte vigtige årstal fra bogen} Selve kalenderdelen tager sin begyndelse i 1901, hvor brydningskoncessionen på kryolit i Ivittuut forlænges til 1925. Den årlige produktion udgør $4.900 \mathrm{~m}^{3}$. I 1909 observeres det første guldkorn! Det blev fundet i Josvakobberminen i det sydvestlige Grønland. 10 år senere offentliggør Lauge Koch de første videnskabelige resultater, som han har indsamlet under den 2. Thuleekspedition 1916-

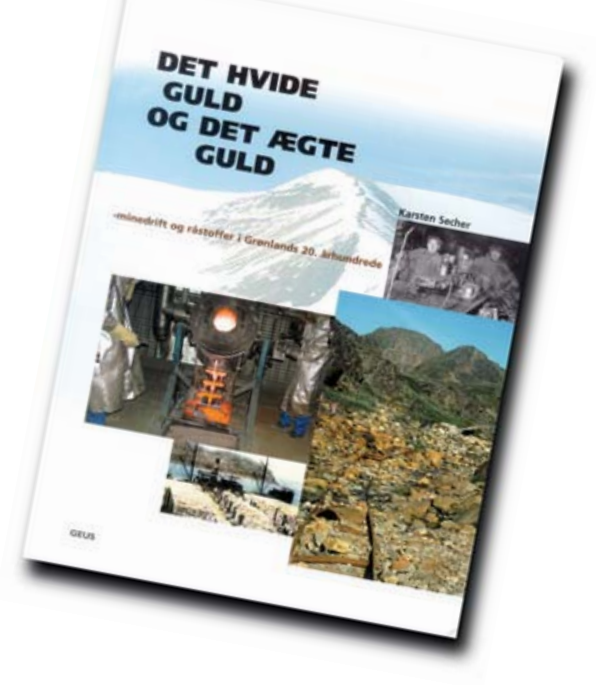

18 (første ekspedition fandt sted i 1912-13).

I et digert værk på tre bind, Mining in Greenland, bidrager Bøggild i 1929 til at fremme betydningen af råstofudvindingen. Året efter lykkedes det Alfred Wegener, tysk geofysiker og glaciolog, at måle og beregne Indlandsisens maksimale tykkelse til mere end $1.800 \mathrm{~m}$

I 1935 udgiver Lauge Koch "Geologie von Grönland", der starter striden mellem Koch og "de 11 geologer" (se GeologiskNyt 3/4), og som juridisk afgøres i 1938 ved højesteret. 3-4 år senere findes der galenit- og zinkblendeholdige malmstykker øst for Uummannaq - det der senere føre til oprettelsen af "Den sorte Engel" i 1973.

Under krigen i 1943 byggede amerikanerne to militærbaser for at sikre produktionen af kryolit (og der med aluminiumsproduktionen).

I 1952 åbnes en stor blymine i Mesters- vig i Østgrønland, og 5 år senere finder geologen Henning Sørensen det kendte lillarøde mineral, tugtupit.

10 år senere stopper minedriften af kryolit i Ivittuut; i 1964 dør Lauge Koch. 60erne var i det hele taget et begivenhedsrigt årti; Kryolitselskabet Øresund opdagede en kæmpe jernforekomst i nærheden af Nuuk på næsten 2 mia. tons malm med en gennemsnitslødighed på $32 \%$, og desuden opdagede man den populære smykkesten "Grønlandit" - med en alder på 3.700 mio. år!

Den kendte bly-zinkmine "Den sorte Engel" ved Maarmolrilik starter malmproduktionen i 1973. 6 år senere får Grønland hjemmestyreordningen, hvor råstoffer og retten til undergrunden anerkendes som den fastboende befolknings "grundlæggende" rettighed, men ikke dens ejendomsret.

I 1987 sejles sidste ladning kryolit væk fra Ivittuut, der lukkes som mineby; ligeledes ophører minedriften i "Den sorte Engel".

NunaOils geologer finder det første guld $i$ fast fjeld i 1992, og i 2000 overtager minedriften af det ægte guld pladsen fra det "hvide guld"!

\section{Spændende og flot bog}

Bogen veksler mellem gamle sort-hvidfotos, illustrerende kort og flotte farvebilleder kombineret med informationsspækket tekst, så man får en fin fornemmelse af historiens spændende gang. Virkeligt en bog, der er informativ og samtidigt flot sat op.

Det hvide guld og det agte guld af Karsten Secher, (GEUS), 64 sider, gennemillustreret. Bogen koster $200 \mathrm{kr}$. (incl. moms) og kan købes hos GEUS eller Geografforlaget. Bogen findes også $i$ en grønlandsk udgave. ISBN: 87-7871-125-8. 